GM

24,4

232

Received 25 September 2008 Revised 29 December 2008 Accepted 5 January 2009

\section{Constraints and opportunities facing women entrepreneurs in developing countries}

\section{A relational perspective}

\author{
Dima Jamali \\ Olayan School of Bussiness, American University of Beirut, Beirut, Lebanon
}

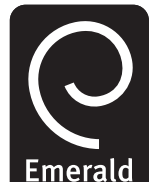

Gender in Management: An International Journal

Vol. 24 No. 4, 2009 pp. $232-251$

(c) Emerald Group Publishing Limited 1754-2413

DOI $10.1108 / 17542410910961532$

\begin{abstract}
Purpose - This purpose of the paper to examine the interplay of constraints and opportunities affecting female entrepreneurship in developing countries. The paper integrates salient micro- and macro-level perspectives and provides a rounded account of opportunities and constraints as part of a holistic interdependent system.

Design/methodology/approach - The paper adopts an integrative multi-level research design and an interpretive research methodology, capitalizing on in-depth interviews with ten women entrepreneurs to explore their perceptions and interpretations of constraints and opportunities facing female entrepreneurship in the Lebanese context.

Findings - The findings presented in this paper clearly illustrate the relevance of micro-, meso-, and macro-level factors in entrepreneurship research and the usefulness of integrating multiple lens and units of analysis to capture the complexity of the women entrepreneurship experience in any particular context.

Originality/value - The value added of this research lies in adapting a framework recently popularized in the context of diversity management for use in entrepreneurship research, helping to capture in turn the dynamic interplay of multiple levels of analysis and objective/subjective factors influencing female entrepreneurship.
\end{abstract}

Keywords Women, Entrepreneurs, Entrepreneurialism, Developing countries, Lebanon

Paper type Research paper

\section{Introduction}

Female entrepreneurship has attracted increasing attention in recent years in light of concrete evidence of the importance of new business creation for economic growth and development (Acs et al., 2005; Langowitz and Minniti, 2007). Not only does female entrepreneurship contribute to economic growth and employment creation, but it is increasingly recognized to also enhance the diversity of entrepreneurship in any economic system (Verheul et al., 2006) and to provide avenues for female expression and potential fulfillment (Eddleston and Powell, 2008). These benefits are rarely leveraged in a systematic way, however, given that female entrepreneurship talent and potential remain largely untapped in many contexts (Baughn et al., 2006).

There is indeed accumulating evidence suggesting that although the rate at which women are forming businesses has increased significantly, the rates of female entrepreneurial activity are significantly and systematically lower than those for males (Minniti et al., 2005; Verheul et al., 2006; Langowitz and Minniti, 2007). Minniti et al. (2005) document in this respect substantial variations in entrepreneurship rates across 
countries participating in the Global Entrepreneurship Monitor (GEM) in 2004, with men more active in entrepreneurship in all countries. Generally, countries with high female entrepreneurial activity rates also tended to be characterized by high total entrepreneurial activity rates (Verheul et al., 2006).

While the literature on female entrepreneurship has traditionally focused on the micro-level, including an exploration of the distinctive characteristics of female and male entrepreneurs in terms of motivation, personality traits, or experience for example, or the features of their firms as in size, goals, access to capital, management, and performance, more systematic attention has been accorded in recent years to the influence of macro-level factors on entrepreneurship generally, and female entrepreneurship specifically (Verheul et al., 2006; Baughn et al., 2006). However, we believe that both sets of factors are important to provide a comprehensive understanding of female entrepreneurship in a particular context, consistent with the integrative multi-level research design advocated by Davidsson and Wiklund (2001) and more recently by Bruin et al. (2007).

There is indeed little doubt that determinants of female entrepreneurship lie in a complex interplay of micro-, meso-, and macro-level factors (Bruin et al., 2007). While gender differences have indeed been documented at a micro-level in relation to self-perception (Anna et al., 2000), opportunity recognition (Eckhardt and Shane, 2003), decision-making styles (Baker and Nelson, 2005), and network structures/networking behavior (McManus, 2001), there is an increasing realization that individual orientations are enmeshed and molded by economic, legal, normative and societal environments, supporting the thesis of entrepreneurship embedded-ness in specific socio-cultural contexts (Bruin et al., 2007; Baughn et al., 2006). Individual orientations are also closely intertwined with meso level factors, including prevailing organizational processes, policies and practices. Single level conceptualizations may thus prove to be simplistic, failing to capture the interplay among different units and levels of analysis.

It is precisely in this context that we seek to explore opportunities and constraints facing women entrepreneurs in developing countries, using a relational multi-level framework design as recently suggested by Syed and Ozbilgin (in press) in the context of diversity management. After a brief overview of the literature pertaining to female entrepreneurship, integrating salient micro-, meso-, and macro-level perspectives, the paper presents an exploratory study documenting the perceptions of a sample of Lebanese women entrepreneurs of different factors affecting the establishment and development of their small business. While particular attention is accorded to perceptions of micro and macro-level factors influencing female entrepreneurship in transition economies, we also integrate insights into the salience of meso level factors as appropriate and highlight the study's implications for future directions in women entrepreneurship research.

\section{Factors affecting female entrepreneurship}

The most popular themes in entrepreneurship research have traditionally revolved around micro-level factors including opportunity recognition, motivation, financing and performance. Opportunity identification is considered a mainstream fundamental issue in entrepreneurship research, given that it is an important entrepreneurial capability and a source of competitive advantage (DeTienne and Chandler, 2007).
Constraints and opportunities facing women

233 
GM

24,4

234

Gender differences in opportunity identification have been linked to differences in human capital variables including education and work experience, with men documented to leverage significantly higher levels of prior industry or entrepreneurial experience as well as experience in managing employees than women (Carter and Brush, 2005; Carter and Williams, 2003; Boden and Nucci, 2002). While men and women may indeed have unique and differentiated stocks of human capital as recently implied by DeTienne and Chandler (2007), the evidence generally suggests that women have less human capital to bring to self-employment which negatively impacts their opportunity identification and exploitation potential.

The motives for pursuing entrepreneurship have also received systematic attention, with various authors referring to gender inequality as a push factor for female entrepreneurship in developed and developing economies (Aidis et al., 2007; Baughn et al., 2006). In other words, for many female entrepreneurs, the choice of self-employment may reflect the restricted structure of opportunities in the labor market, labor market discrimination or glass ceiling career problems, with self-employment often perceived as a survival strategy, or as a means of providing flexibility in work scheduling and reconciling multiple roles (Baughn et al., 2006). Pull factors are also important revolving around opportunities for independence, challenge, initiative as well as the success and satisfaction derived through entrepreneurship (Hughes, 2003; Baughn et al., 2006), with research suggesting different sets of career satisfiers for men and women entrepreneurs, revolving around status attainment for the former and social relationships and goals for the latter (Eddleston and Powell, 2008).

In relation to financing, the evidence generally reveals that female entrepreneurs start with lower levels of overall capitalization and lower ratios of debt finance than their male counterparts (Bruin et al., 2007). Carter and Kolvereid (1997) found for example that women had greater limitations in accessing personal savings, given more punctuated and interrupted work histories and lower patterns of remuneration. Shaw et al. (2001) similarly suggest that women are less likely to have generated a credit track record to establish formal credit worthiness than their male counterparts. Female entrepreneurial ventures also tend to be concentrated in service sectors that are usually cheaper and easier to establish (Carter et al., 2001) and both male and female entrepreneurs tend to tap mostly into savings and family support (Cosh and Hughes, 2000). Hence, there have been various associations between gender disadvantage and funding, often characterized as chronic gender related under-capitalization barriers (Marlow and Patton, 2005; Carter et al., 2001), which in turn lead to long-term under performance.

Consequently, it should come as no surprise that women-owned businesses tend to be smaller, slower growing and less profitable than those owned by men (Greene et al., 2003). Objective performance measures have traditionally been used in the context of female entrepreneurship, including turnover and employment growth, and only recently have those been complemented by attention to outcomes other than financial measures, including self-stated growth and the interdependence between performance, success and personal goals (Bruin et al., 2007). Gender is considered to play a role in new venture performance, given that it influences the self-perception of women entrepreneurs and their abilities to realize business growth in a particular environment (Bruin et al., 2007). Performance and growth are also certainly affected 
by prevailing role expectations, the nature and extent of family support, as well as family and household responsibilities. Hence, performance in the context of female entrepreneurship is recognized as a complex construct, affected by various antecedents and extraneous factors.

The literature review has thus focused to this point on micro-level factors affecting female entrepreneurship, including opportunity identification, motivation, resources/financing strategies, and performance. However, the complex interweaving and entanglement of micro-, meso-, and macro-level variables can be clearly detected even as we tried to set a distinction between these levels. For example, human capital constraints or push factor type motivations are inextricably linked to organizational processes or labor market constraints as well as various macro normative and socio-cultural variables. Similarly, performance and growth as indicated above are affected by societal role expectations and availability of support. Self-perception and desire for growth are in turn invariably influenced by the status, desirability and credibility society attaches to women employment, self-employment and business success. Hence, micro-, meso-, and macro variables interweave to shape the general experience of female entrepreneurship in any specific context.

Some literature has accorded attention to macro-level variables specifically; differences in rates of entrepreneurial activity across countries detected in the GEM studies for example suggest that start-up rates are indeed molded by peculiar structural characteristics of a given country (Reynolds et al., 2003). Baughn et al. (2006) note that the level of entrepreneurial activity can be seen as embedded in a country's economic, socio-cultural and legal environment. Arenius and Minniti (2005) propose grouping macro-level factors influencing entrepreneurship into two categories including socio-economic factors and contextual factors and to supplement those with micro-level perceptual factors. Verheul et al. (2006) have also recently investigated macro-level determinants of entrepreneurship including technological development, economic factors, demographic factors, government intervention and cultural factors, documenting the significant effects of per capita income on entrepreneurial activity. Institutional environments have thus been accorded more systematic attention in recent literature.

Institutional theory has been specifically singled out as a fruitful theoretical lens in the context of female entrepreneurship research (Baughn et al., 2006). Drawing on institutional theory, Scott (1995) enumerates salient regulative and normative pillars of institutions, which promote stability and predictability in social behavior, through compliance with codified laws in the case of the former vs conformity or appropriateness in the case of the latter. North (1990) refers to those two pillars as the visible vs invisible rules of the game, respectively. In relation to female entrepreneurship, the normative pillar is particularly salient in the sense that career choices are clearly shaped by what society deems desirable and correct for one sex and that many societies continue to define women through roles associated with family responsibilities (Achtenhagen and Welter, 2003; Welter et al., 2003). Moreover, traditional male stereotyping of entrepreneurship may discourage women from pursuing new ventures (Bird and Brush, 2002). Differences in the social acceptability of female entrepreneurs have also been noted as salient across institutional environments (Reynolds et al., 2003), with lower credibility and legitimacy ascribed to female entrepreneurship risking to constrain the rates of female start-ups (Baughn et al., 2006).

\section{Constraints and opportunities facing women}

235 
GM

24,4

236

As suggested by Verheul et al. (2006), entrepreneurship is also related to the level of economic development and is embedded in a specific national economic context. For example, high levels of self-employment are often reported in countries with low levels of economic development (Baughn et al., 2006). Similarly, the evidence tends to suggest that increasing economic prosperity is associated with decreasing rates of self-employment (given the increased attractiveness of wage employment as well as the opportunity cost of self-employment), although this may not apply to the most prosperous countries (Nooderhaven et al., 2004). Accumulated data through the GEM project indeed support the existence of a curvilinear relationship between GDP and entrepreneurial activity, with the highest levels of activity reported in less prosperous nations (motivated by push factors) and the lowest levels of entrepreneurial activity reported in the middle income nations (Acs et al., 2005; Baughn et al., 2006).

Hence, there is little doubt that female entrepreneurship is affected by a complex blend of micro-, meso-, and macro-level variables, although this has not been systematically accounted for in previous research (Ahl, 2006; Bruin et al., 2007). According to Bruin et al. (2007, p. 334) "most researchers take the current units of analysis - the entrepreneur, the co-preneur, or the venture - for granted, without questioning its applicability to women's entrepreneurship." It is precisely in this context that we recommend moving away from single level conceptualizations to a multi level relational framework or design as recently suggested by Syed and Ozbilgin (in press) in the context of diversity management. As illustrated in Figure 1, the relational framework bridges micro-individual, meso-organizational and macro-national levels of analysis, helping to place and understand phenomena in their peculiar macro national and historical contexts.

Adapting the relational framework to the study of entrepreneurship, there is a need to understand the reciprocal influences and interplay of three sets of factors in

Figure 1.

A relational framework for entrepreneurship research



Source: Adapted from Syed and Ozbilgin (in press) 
entrepreneurship research. The macro national level involves structural conditions, including social values, social stratification, conception of law, family and work and is the all encompassing domain within which all other layers exist (Syed and Ozbilgin, in press). The micro-individual level includes factors like individual agency, motivation, identity and various forms of human capital that influence individual capabilities and opportunities, while the meso level involves organizational processes that mediate employment opportunities according to individual abilities and contextual circumstances (Syed and Ozbilgin, in press). The interplay of different levels of analysis is nicely captured and supplemented by attention to the role of historical traditions which tend to permeate the perpetuation of specific societal beliefs.

The relational framework can help contextualize the study of entrepreneurship according to local multi level factors. It turns attention to the need to anchor entrepreneurship research in a specific socio-economic context, integrating insights into aspects of social and economic change, ideologies of gender relations and institutional and legal developments (Syed and Ozbilgin, in press). Moreover, it tackles the relational interplay of structural and agency level concerns helping to reconcile objective structures/measurable attributes and processes with subjective experiences and interpretations (Syed and Ozbilgin, in press). Of particular interest is the characterization of different levels of analysis as interdependent and inter-related hence the term relational - with the implication that entrepreneurship is socially and historically embedded but also at some level individually constructed and negotiated.

We turn our attention specifically here to the Lebanese context and attempt to explore factors influencing women entrepreneurship in the frame of an integrative multi-level research design. The research methodology is interpretive in nature capitalizing on insights derived from in-depth interviews with a sample of Lebanese women entrepreneurs documenting their perception of the salience of different sets of factors affecting their start up ventures. Relevant implications are delineated accordingly.

\section{Brief background information about working women in Lebanon}

Lebanon is an Arab country and a founding member of the Arab league. Females in the traditional Arab culture have been viewed mostly in terms of their roles as mothers and caretakers of the home. The socio-political and economic changes impinging on the Arab world over the past few decades, however, have affected this perception to varying degrees in different Arab contexts. Lebanon is among the few Arab countries that have allowed women to increasingly assume functions outside the traditional mother-home roles. This is due to several reasons, many of which are peculiar to Lebanon (Sidani, 2002). In the first instance, Lebanon has traditionally been more open to the West compared to other Arab countries. In addition, the heavy migration of males, in search of better pay and work opportunities, to the Arab Gulf oil-producing countries in the eighties and nineties reflected in shortages in the male working force and catalyzed an influx of women into non-traditional jobs. In the wake of the civil war in 1990, further economic changes necessitated that women participate more aggressively in the country's development. Worsening economic conditions implied that many homes could only survive if supported by dual-career couples. Hence, over the past decades, significant consideration has been accorded to the role of women in Lebanon, resulting in relative progress and an influx of women into new sectors.
Constraints and
opportunities
facing women

237 
GM

24,4

238

Table I.

Female economic activity rate in lebanon and selected world regions
Perceptions of Lebanon as a country where women have long enjoyed freedoms and rights that their counterparts in neighboring Arab countries have been striving for do not however reflect the complete picture. Statistics about women participation in the economic and political spheres do not tell a story that is exceptionally bright. On the one hand, educational enrollment of women has steadily improved with women's post secondary educational enrollment nearing 50 percent in both public and private educational sectors. For example, more than half of all university students are women - 53 percent in 2001 (World Bank, 2005). On the other hand, the economic involvement of women did not fare as well. While the economic activity rate of women has increased from its 17.5 percent level in the early 1970s, it has nonetheless been estimated at a modest 32.4 percent in 2007 (41 percent of the male rate - HDR, 2008). The women estimated earned income was USD 2,701 in 2005 compared to USD 8,585 for males (HDR, 2008). The participation of women in public life also remains marginal. A meager four percent of the Lebanese parliament members are women and women lead only two out of more than 700 municipal councils (Sha'rani, 2004). Table I summarizes relevant indicators pertaining to the economic activity of women in Lebanon in comparison to selected world indicators.

Very few reliable statistics are available, on the other hand, documenting the rates of female entrepreneurship in Lebanon. A study by Pistrui et al. (2008) suggests that entrepreneurship is not an exclusively male activity in Lebanon, yet estimates the rate of female entrepreneurial activity in the country at a modest 15 percent. This estimation is consistent with earlier studies, which documented in 2002 that self-employed women constitute 11.6 percent of the female labor force, which is significantly less than the rates of self-employment for men (estimated at 29.6 percent of the male labor force) (ESCWA, 2004). Based on trend analysis and in the absence of official and reliable statistics about rates of female entrepreneurship in the country, it is safe to assume that there have not been significant changes in these rates over the past few years.

Earlier studies also document the concentration of Lebanese female entrepreneurs in the small trade and service industries and their reliance on personal and family savings to support their new ventures (IFC, 2007; Samaha, 2007). Husseini (1997) reports that Lebanese women entrepreneurs have smaller sized businesses compared to men and are disadvantaged in terms of securing external bank financing. Very few indeed resort to external sources of financing as suggested by the IFC (2007), which reports that Lebanese women comprise about 35 percent of micro credit borrowers in contrast to a rate of 60 percent for most of the Arab world. These observations are supported by other studies (IFC and CAWTAR, 2007) where Lebanese women entrepreneurs reported concerns relating primarily to access to capital and the high cost of public services.

\begin{tabular}{lcc}
\hline 2008 & Female economic activity rate (\%) & As a percentage of male rate \\
\hline Lebanon & 32.4 & 41 \\
Arab states & 26.7 & 34 \\
Developing countries & 52.4 & 64 \\
OECD & 50.3 & 72 \\
World & 52.5 & 67
\end{tabular}

Source: HDR (2008) 
Lebanese women entrepreneurs are similarly disadvantaged in terms of access to business networks, given that they comprise a very small percentage of the memberships and boards of almost all syndicates and chambers of commerce and/or industry (Sha'rani, 2004). This may translate into fewer opportunities for networking, partnering, identifying new opportunities, and expanding new ventures. Lebanese female entrepreneurs are also certainly constrained by a patriarchal culture (Haddad, 1993) that continues to ascribe caring and family responsibilities to women and is permeated by various traditional masculine stereotypes (Jamali et al., 2005; Jamali et al., 2006). Lebanese society indeed accords primary importance to the role of the family, with strong family ties cemented and sustained in what is still considered as a collectivist culture (Sidani, 2002).

It is also worth mentioning that all Lebanese entrepreneurs, irrespective of gender, have faced significant hurdles and constraints in recent years, in light of a daunting economic recession (for example gross public debt stood at 177 percent of GDP in June 2004 - IIF, 2005) and a serious political stalemate. The fermenting of this stalemate started with the assassination of former Prime Minister Rafik Hariri in 2005 and translated in 2007 into a political vacuum at the highest level with the inability to elect a President for Lebanon due to political tensions and disagreements. These contextual conditions have no doubt exacerbated the difficulties experienced by female entrepreneurs specifically, rendering it even more difficult to navigate and maneuver in the complex labyrinth of Lebanese society. We turn next to examine those realities and perceptions more closely based on our primary research component.

\section{Research focus and methodology}

The research undertaken is interpretive in nature (Gephart, 2004), capitalizing on in-depth interviews with women entrepreneurs to explore their interpretations and perceptions of female entrepreneurship in Lebanon. Interpretive research is qualitative seeking to unearth collective frames of reference, or construed realities that guide the attribution of meaning and help account for how women create, enact or interpret the reality they inhabit (Patton, 2002). A purposeful sample comprising ten women entrepreneurs was used for this research. According to Patton (2002), qualitative inquiry typically focuses in-depth on relatively small samples, selected purposefully (whereas quantitative methods focus on larger samples selected randomly). "The logic and power of purposeful sampling lie in selecting information rich cases to study in depth; Information rich cases are those from which one can learn a great deal about issues of central importance to the purpose of the inquiry" (Patton, 2002, p. 230).

In the frame of this logic, this research selectively included ten women entrepreneurs with relevant entrepreneurship experience. The sampling was purposeful in the sense that only women entrepreneurs who had initiated new ventures and accumulated relevant experience with start up businesses were approached. As illustrated in Table II, the women entrepreneurs were drawn from different age groups (e.g. 34 years old to 60 years old) and different sectors (e.g. consumer and domestic goods, consulting, auditing, insurance, travel, and education) thus bringing a variety of vantage points and perspectives. Nine were married (and one divorced) and all had children and caretaker responsibilities. Most of the women entrepreneurs in the sample also have relevant academic qualifications (the majority

\section{Constraints and opportunities facing women}

239 
GM

24,4

240

\begin{tabular}{|c|c|c|c|c|c|}
\hline $\begin{array}{l}\text { Woman } \\
\text { entrepreneur }\end{array}$ & Line of business & Education & $\begin{array}{l}\text { Prior work } \\
+ \text { years }\end{array}$ & Age & $\begin{array}{l}\text { Children/marital } \\
\text { status }\end{array}$ \\
\hline 1 & $\begin{array}{l}\text { Owner of } \\
\text { consultancy firm }\end{array}$ & $\begin{array}{l}\text { Diploma holder in } \\
\text { air stewardship }\end{array}$ & $\begin{array}{l}\text { Airhostess } / 6 \\
\text { years }\end{array}$ & 48 & $\begin{array}{l}2 \text { Children } \\
\text { married }\end{array}$ \\
\hline 2 & $\begin{array}{l}\text { Owner of apparel } \\
\text { store }\end{array}$ & $\begin{array}{l}\text { Bachelor of } \\
\text { business } \\
\text { administration }\end{array}$ & Bank/8 years & 42 & $\begin{array}{l}2 \text { Children } \\
\text { married }\end{array}$ \\
\hline 3 & $\begin{array}{l}\text { Owner of wedding } \\
\text { organizing firm }\end{array}$ & Graphic design & $\begin{array}{l}\text { Graphic } \\
\text { designer/4 years }\end{array}$ & 35 & $\begin{array}{l}3 \text { Children } \\
\text { married }\end{array}$ \\
\hline 4 & $\begin{array}{l}\text { Owner of sportswear } \\
\text { store }\end{array}$ & $\begin{array}{l}\text { Bachelor of } \\
\text { business } \\
\text { administration }\end{array}$ & $\begin{array}{l}\text { Family sports } \\
\text { business/7 years }\end{array}$ & 34 & 1 Child married \\
\hline 5 & Owner of audit firm & $\begin{array}{l}\text { Bachelor of } \\
\text { business } \\
\text { administration }\end{array}$ & $\begin{array}{l}\text { Accounting } \\
\text { job/10 years }\end{array}$ & 44 & 1 Child married \\
\hline 6 & $\begin{array}{l}\text { Owner of vocational } \\
\text { educational centre }\end{array}$ & $\begin{array}{l}\text { Bachelor of arts in } \\
\text { education }\end{array}$ & $\begin{array}{l}\text { School teacher/8 } \\
\text { yrs }\end{array}$ & 60 & $\begin{array}{l}3 \text { Children } \\
\text { married }\end{array}$ \\
\hline 7 & $\begin{array}{l}\text { Owner of insurance } \\
\text { company }\end{array}$ & $\begin{array}{l}\text { Masters of business } \\
\text { administration }\end{array}$ & $\begin{array}{l}\text { Administrative } \\
\text { position/12 years }\end{array}$ & 50 & $\begin{array}{l}2 \text { Children } \\
\text { married }\end{array}$ \\
\hline 8 & $\begin{array}{l}\text { Owner of travel } \\
\text { agency }\end{array}$ & $\begin{array}{l}\text { Bachelor of } \\
\text { business } \\
\text { administration }\end{array}$ & $\begin{array}{l}\text { Administrative } \\
\text { position/15 years }\end{array}$ & 54 & $\begin{array}{l}3 \text { Children } \\
\text { married }\end{array}$ \\
\hline 9 & $\begin{array}{l}\text { Owner of } \\
\text { consultancy firm }\end{array}$ & $\begin{array}{l}\text { Bachelor of } \\
\text { business } \\
\text { administration }\end{array}$ & $\begin{array}{l}\text { Free lance } \\
\text { consultant } / 9 \\
\text { years }\end{array}$ & 56 & 1 Child married \\
\hline 10 & $\begin{array}{l}\text { Owner of furniture } \\
\text { store }\end{array}$ & Bachelor of arts & $\begin{array}{l}\text { Store } \\
\text { manager/6 years }\end{array}$ & 37 & $\begin{array}{l}2 \text { Children } \\
\text { divorced }\end{array}$ \\
\hline
\end{tabular}

Table II.

Sample profile hold a degree in business administration) but only half had relevant prior work experience (e.g. no. 4; no. 5; no. 6, no. 9, and no. 10).

An interview guide was prepared based on the literature review presented above. The interview guide addressed micro and macro level factors affecting female entrepreneurship as reflected in Table III. The interview guide served the purpose of steering discussions around common themes (relating for example to opportunity identification, motivation, financing strategies, performance, legal environment, normative environment, and economic environment), while also leaving the interviewer to decide on the sequence and wording of questions in the course of the interview. All interviews were conducted in English, lasted on average $2 \mathrm{~h}$, and were tape recorded and transcribed.

Following the transcription of the interviews and the codification of data with regard to the basic dimensions outlined in Table III, the analysis focused on detecting commonalities or patterns of agreement/convergence in the statements provided, but areas of divergence were equally noted/highlighted. Dimensions were considered most salient when they were repeatedly emphasized by interviewees in the context of the discussions held. This is consistent with a grounded theory analytical approach as espoused by Glaser and Strauss (1967) with points that participants tended to repeat serving to augment or support particular theoretical insights (i.e. emphasis on micro vs macro level factors in the context of a relational framework). 


\begin{tabular}{|c|c|c|c|}
\hline & Dimension & Description & onnortunities \\
\hline \multirow[t]{5}{*}{ Micro level factors } & $\begin{array}{l}\text { Opportunity } \\
\text { identification }\end{array}$ & $\begin{array}{l}\text { How women entrepreneurs identified } \\
\text { opportunity for the new business and human } \\
\text { capital variables (e.g. education and work } \\
\text { experience); barriers encountered in terms of } \\
\text { opportunity exploitation } \\
\text { Motives for pursuing entrepreneurshin }\end{array}$ & facing women \\
\hline & Motivation & $\begin{array}{l}\text { Motives for pursuing entrepreneurship } \\
\text { including push and pull factors (e.g. labor } \\
\text { market constraints vs seeking challenge and } \\
\text { independence) }\end{array}$ & \\
\hline & Financing & $\begin{array}{l}\text { Strategies and sources of financing that } \\
\text { women entrepreneurs tapped into and } \\
\text { barriers encountered in this process }\end{array}$ & \\
\hline & Performance & $\begin{array}{l}\text { Performance of the business in terms of } \\
\text { turnover and growth }\end{array}$ & \\
\hline & & $\begin{array}{l}\text { Self-stated growth objectives and the } \\
\text { interdependence between performance, } \\
\text { success, and personal goals }\end{array}$ & \\
\hline \multirow[t]{3}{*}{ Macro level factors } & Legal environment & $\begin{array}{l}\text { Explicit regulations pertaining to small } \\
\text { business creation/sustenance that Lebanese } \\
\text { female entrepreneurs considered salient (e.g. } \\
\text { government procedures, labour market } \\
\text { legislation, formal gender equality by law) }\end{array}$ & \\
\hline & Normative environment & $\begin{array}{l}\text { Unwritten rules of conduct and behaviour } \\
\text { consisting of norms, values, societal roles, } \\
\text { family values, religious beliefs, traditional } \\
\text { attitudes, stereotyping, credibility and } \\
\text { legitimacy of self-employment }\end{array}$ & \\
\hline & Economic environment & $\begin{array}{l}\text { The objective and perceived nature of the } \\
\text { economic environment and how this reflects } \\
\text { on female entrepreneurship intentions and } \\
\text { exploitation }\end{array}$ & Table III. \\
\hline $\begin{array}{l}\text { Micro and macro level } \\
\text { factors }\end{array}$ & Constraints/opportunities & $\begin{array}{l}\text { Ranking of main obstacles encountered } \\
\text { identification of opportunities and reasons for } \\
\text { success }\end{array}$ & $\begin{array}{r}\text { Interview guide } \\
\text { addressing micro and } \\
\text { macro level factors }\end{array}$ \\
\hline
\end{tabular}

For the paper at hand, the critical task was to determine substantive significance. As per Patton (2002) qualitative findings are judged by their substantive significance, which is determined in turn by how solid, coherent and consistent the evidence is, and how the findings increase or deepen our understanding of the phenomenon in question, and to what extent the findings are consistent with other knowledge. The author analyzed case study content and outlined through a systematic comparative process areas of substantive significance in relation to the main categories outlined in Table III. The findings are fleshed out in the next section in the aggregate, with the identities of the women entrepreneurs concealed for confidentiality reasons.

\section{Research findings}

Starting with micro-level factors, the women entrepreneurs identified opportunities for their new business ventures through various mechanisms, including work experience 
GM

24,4

242

in the same field or personal aspirations sometimes influenced by friends and husbands. Several of the women entrepreneurs indeed admitted jointly identifying opportunities for the new business with their husbands. Conversely, two of the women interviewed admitted initiating the new venture in defiance of their husbands, who were not entirely convinced of their ability to break through and succeed. According to one of the interviewees, "I established my own business, which is related to brain drain problems; it was initially my husband's idea and I challenged him to proceed in it and to succeed." The majority of the women entrepreneurs in the sample leveraged differentiated stocks of human capital as reflected in relevant educational qualifications and industry experience, although a few admittedly embarked on the new journey with no prior relevant experience, seeking challenge, flexibility, and better incomes.

The motives for pursuing entrepreneurship were also systematically explored, and most women referred to an interesting combination of push and pull factors. In terms of push factors, six women entrepreneurs mentioned specifically labor market discrimination and frustration with gender pay discrepancies and glass ceiling barriers. According to one of the interviewees, "I was deeply frustrated with previous unfair treatment and it was very hard for me to entertain working for an employer again.” All ten women entrepreneurs with no exception also made reference to the flexibility provided through entrepreneurship as an important push factor. Several women mentioned the need for a double income to sustain the family as an important push factor. Various pull factors were conversely mentioned by the women entrepreneurs interviewed, including the pursuit of challenge, creativity, and financial independence. According to one of the women entrepreneurs "I was always longing to be independent, to run my own business, and to take control of my life and my career."

In terms of financing strategies, the majority of women entrepreneurs tapped into family or personal savings, and many turned to their husbands and/or brothers for financial support. Seven of the women interviewed indeed alluded to the limitations of accessing "personal" savings and having to turn to supporters and sponsors (mostly male) from within the family. According to one of the interviewees, "The initial funding came from my family; my brother supported me financially and emotionally; moreover, he introduced me to many clients." Another woman entrepreneur put it in those words:

The initial funding came from our family savings; but that was not enough, we had to purchase the premises and we did this through an installment plan given by the previous owner. We did not even consider bank financing as a viable option at the time.

It is clear that initial lack of access to capital and financial support or under-capitalization barriers as mentioned in the literature were considered salient by most of the women entrepreneurs. As articulated by one of the interviewees, "Lack of financial support was and still is a problem. I want to move into different premises, larger and in a different area, but I cannot, because of the capital requirements."

In the area of performance, the majority of the women entrepreneurs expressed satisfaction with the performance of the business, despite the various constraints encountered along the way. According to one of the managers "I am very satisfied with the growth of my business because I doubled my capital; I am also so proud of the reputation that the business has acquired." Several of the women entrepreneurs 
referred to important satisfiers derived through entrepreneurship besides financial growth. As echoed by one of the women interviewed:

I love my work and I still come almost every day; I feel that in addition to the income generated from the business, we are rendering a very important social service by providing vocational education to thousands of children.

Several of the female entrepreneurs also referred to the recent political instability and economic stagnation as having detrimentally affected the growth of their business and some made reference to stiffer trends of local and regional competition.

Turning to macro level factors, very few women mentioned legal-type constraints, and all conversely expressed vocal and explicit concern with normative type constraints. This was a theme that was indeed consistently echoed across all the interviews. The interviewees specifically complained about traditional male stereotypes associated with entrepreneurship in Lebanon, the difficulty of reconciling family and work responsibilities, and societal and family pressures and disapproval of women leaving their kids in pursuit of employment and career success. As expressed by one of the interviewees:

Most of the clients expect the woman entrepreneur to have male characteristics, mainly aggressiveness and dominance. Sometimes, they accused me of being a dominant person only because I was running my own business.

All interviewees without exception expressed concern about striking a balance between family life and business life as a serious constraint. As put by one of the women interviewed, "The main problem is to cope and to balance between work and family and to convince the husband to be more involved in family and child responsibilities." Another manager put it in these words, "The most important barrier is family life. My husband was initially encouraging and supportive of me as I started the business; however, we began to argue as I was spending more and more time at work."

Several women also expressed normative pressures stemming from traditional attitudes of a conservative society where women are expected first and foremost to deliver on their family duties and responsibilities. According to one of the interviewees, "At the personal level, I experienced lack of support and outright disapproval from my extended family, e.g. sisters and cousins - who thought it was not appropriate for me to neglect my kids in pursuit of this business opportunity." A similar view was expressed by another woman:

I faced disapproving remarks from my family and my husband also had to deal with such attitudes. In our culture, back then, it was probably imprudent for a husband to let his wife work, as if it was a sign of his inability to support his family.

Another female entrepreneur mentioned that "the woman entrepreneur is perceived as someone dedicating more time to her job than her family." The interviewees generally seemed to agree that society does not disapprove of female entrepreneurship per se but of female work more generally. Hence, all female entrepreneurs reported salient normative constraints, stemming from the ascription of women to traditional family roles, the ascription of males to bread winner roles, and the primacy of family life and child-care responsibilities.
Constraints and opportunities facing women

243 
GM

24,4

244

When asked to rank specifically the three most important barriers encountered in the course of their entrepreneurship experience, most female entrepreneurs mentioned the balancing of work and family life as the first and most important barrier, followed by societal attitudes and access to capital. Slight variations in the ranking provided by the ten women entrepreneurs were noted, as illustrated in Table IV, although the constraints identified generally revolved around a common set of themes, with work-family balance featuring systematically across all the interviews. Macro-level constraints also mentioned comprised the lack of access to networks, the lack of government support, and the serious economic recession and stagnation. One of the women entrepreneurs moreover mentioned a legal type constraint relating to "extensive government procedures to register the business." These various constraints are in turn compiled and illustrated in Table IV.

A closer look at Table IV highlights however the acute salience of normative type constraints resulting from the ascription of women to family roles. Other normative constraints encountered included the permeation of entrepreneurship with traditional male stereotypes and societal attitudes not supportive of the work of women in general. Various macro level constraints were also identified including lack of government support, the ailing economy as well as legal type constraints relating to extensive government procedures, suggesting the salience of structural barriers to female

\begin{tabular}{|c|c|c|c|}
\hline $\begin{array}{l}\text { Woman } \\
\text { entrepreneur }\end{array}$ & Obstacle 1 & Obstacle 2 & Obstacle 3 \\
\hline 1 & $\begin{array}{l}\text { Finding time for family } \\
\text { life and childrearing } \\
\text { functions }\end{array}$ & $\begin{array}{l}\text { Societal ascriptions to } \\
\text { family roles }\end{array}$ & $\begin{array}{l}\text { Government procedures } \\
\text { to register the business }\end{array}$ \\
\hline 2 & $\begin{array}{l}\text { Striking a balance } \\
\text { between work and family }\end{array}$ & $\begin{array}{l}\text { Societal attitudes not } \\
\text { supportive of working } \\
\text { women }\end{array}$ & Economic stagnation \\
\hline 3 & $\begin{array}{l}\text { Family life and creating } \\
\text { quality time for the kids }\end{array}$ & $\begin{array}{l}\text { Husband involvement in } \\
\text { the family }\end{array}$ & $\begin{array}{l}\text { Long hours required to } \\
\text { ensure the business } \\
\text { thrives }\end{array}$ \\
\hline 4 & $\begin{array}{l}\text { Finding time for family } \\
\text { and childcare } \\
\text { responsibilities }\end{array}$ & $\begin{array}{l}\text { Working long hours and } \\
\text { late, as well as } \\
\text { holidays/afternoons }\end{array}$ & $\begin{array}{l}\text { Lack of access to relevant } \\
\text { social/business networks }\end{array}$ \\
\hline 5 & $\begin{array}{l}\text { Time, time needed which } \\
\text { affects family and social } \\
\text { life }\end{array}$ & $\begin{array}{l}\text { Family perception and } \\
\text { approval }\end{array}$ & $\begin{array}{l}\text { Male stereotyping of } \\
\text { entrepreneurship }\end{array}$ \\
\hline 6 & $\begin{array}{l}\text { Societal pressure and } \\
\text { disapproval of my work }\end{array}$ & $\begin{array}{l}\text { Lack of government } \\
\text { support }\end{array}$ & $\begin{array}{l}\text { Lack of financial support } \\
\text { and access to capital }\end{array}$ \\
\hline 7 & $\begin{array}{l}\text { Lack of appreciation for } \\
\text { the value added of my } \\
\text { work }\end{array}$ & $\begin{array}{l}\text { Prevailing role } \\
\text { expectations }\end{array}$ & Economic downturn \\
\hline 8 & $\begin{array}{l}\text { Patriarchal values } \\
\text { permeating family and } \\
\text { social life }\end{array}$ & $\begin{array}{l}\text { Lack of government } \\
\text { support }\end{array}$ & $\begin{array}{l}\text { Lack of governmental } \\
\text { financial support schemes }\end{array}$ \\
\hline 9 & $\begin{array}{l}\text { The work of women } \\
\text { having limited credibility }\end{array}$ & $\begin{array}{l}\text { Male stereotyping of } \\
\text { female entrepreneurship }\end{array}$ & $\begin{array}{l}\text { Lack of networking } \\
\text { opportunities }\end{array}$ \\
\hline 10 & Work life balance & $\begin{array}{l}\text { Lack of support from } \\
\text { extended family }\end{array}$ & $\begin{array}{l}\text { Lack of financial support } \\
\text { and micro credit loans }\end{array}$ \\
\hline
\end{tabular}

Table IV.

Main barriers to female entrepreneurship in lebanon 
advancement in the Lebanese economy and providing tentative support to the need for greater sensitization in consideration of macro level institutional constraints in the context of female entrepreneurship in developing countries generally and Middle Eastern countries more specifically.

In terms of opportunities and success factors, most women referred to being able to overcome these barriers through a combination of personal characteristics including passion, determination, hard work, perseverance, ambition, motivation, responsibility, strong personality, self-confidence, self-efficacy, autonomy, and devotion to work. According to one of the female entrepreneurs, "I would not have succeeded with my new venture, if I was not confident, assertive, ambitious and determined. These characteristics are crucially important to any woman who wants to run her own business." Another woman put it in these words, "I think that women entrepreneurs can be very successful and can run the business better than men because they are more devoted to their work, and more determined to succeed and ascertain their capabilities."

\section{Discussion of findings}

The findings presented in this paper clearly illustrate the interplay of micro and macro-level factors in accounting for female entrepreneurship experience and the usefulness of an integrated framework reflecting the embedded-ness of women entrepreneurship in both micro and macro environments. While opportunities facing women entrepreneurs in this study were mostly identified at the micro level (e.g. opportunity identification and strong motivation), and related to personal characteristics of self-efficacy, resilience and autonomy, these were invariably nested within the contours of a woman's life and overall experiences. Within this overall experience, it was difficult to isolate micro level opportunities from macro level constraints with the accounts provided highlighting their complex interweaving in influencing the rich tapestry of female entrepreneurship experience in any particular context.

In way of illustration, it was difficult to isolate women's entrepreneurial identities from the prevailing societal norms and expectations. Several of the women entrepreneurs seemed to have internalized the caretaker role expectations dominant in Lebanese society, resulting in feelings of guilt when pursuing entrepreneurship despite high levels of aspiration and determination. It was also difficult to isolate women's motivation from meso-level push factors relating to workplace discrimination and glass ceiling constraints. Several of the women entrepreneurs indeed admitted having chosen an entrepreneurial career path as a survival strategy given experienced setbacks and discrimination in previous employment. Moreover, it was difficult to isolate women's motivations from macro level push factors relating to economic stagnation and the need for double income families. These various push factors coexisted with specific pull factors including micro level personal characteristics, orientations and career aspirations. Our findings therefore reinforce the usefulness of considering opportunities and constraints facing women entrepreneurs within a holistic interdependent system, highlighting how the interplay of factors at different levels shapes identities, career choices as well as perceptions of opportunities and constraints.

Furthermore, our findings support the embedded-ness of entrepreneurship and its context specificity, highlighting the strong salience of normative constraints facing
Constraints and opportunities facing women

245 
GM

24,4

246

women entrepreneurs in this peculiar Middle Eastern context, to the extent of undermining their full and fair engagement in entrepreneurship in the current market economy. They also suggest the usefulness of institutional theory as a relevant theoretical lens in the context of entrepreneurship research and that role conflicts are inevitable when norms and practices are so embedded and engrained. Yet our findings do not lend support to blind institutional conformity, suggesting room for active agency in response to institutional constraints as reflected in the resilience and determination of most of the interviewees to persist with their new ventures despite the pressures encountered.

Our findings are consistent with various recent streams in the entrepreneurial literature, which have started to direct attention to the usefulness of a multi level research design in the study of entrepreneurship (Davidsson and Wiklund, 2001 and more recently Bruin et al., 2007). They also lend support to recent research that has tended to challenge the mainstream tendency of taking the entrepreneur as the unit of analysis in women entrepreneurship research as well as the tendency to underestimate the influence of external factors - while overestimating the influence of internal factors (Gartner, 2005). Finally, our study is consistent with recent writings which have alluded to the embedded-ness of entrepreneurship, the usefulness of institutional theory, the greater sensitization of women to normative support, while also integrating the relevance of agency in entrepreneurial accounts (Baughn et al., 2006; Aidis et al., 2007).

What is plausibly unique about our findings is the way they have captured through the interpretive accounts of women entrepreneurs the dynamic interplay of micro-, meso-, and macro-level factors, which to date has been referred to mostly theoretically and in way of future research recommendations (Bruin et al., 2007). They are also unique in way of explicitly addressing macro level factors which have been traditionally neglected in women entrepreneurship research (Ahl, 2006; Bruin et al., 2007). Our findings are finally unique in way of alerting to the specificities of the entrepreneurial experience in the context of developing economies generally and Middle Eastern countries more specifically. While the literature reports on a similar set of constraints facing women entrepreneurs, the stronger salience of normative pressures comes clearly across our findings, reflecting the perpetuation of gendered values and patriarchal norms that continue to permeate Middle Eastern culture influencing the experience and expression of entrepreneurship in that context.

\section{Concluding remarks}

Female entrepreneurship has attracted increasing attention in recent years in light of concrete evidence of its importance for economic growth and development. This paper has examined female entrepreneurship in the Lebanese context, based on in-depth interviews with a sample of ten women entrepreneurs. The accounts provided highlight the suitability of the integrative multi-level research design in women entrepreneurship research and how micro-, meso-, and macro-level factors indeed interweave to shape the experience of female entrepreneurship in any specific context. The insights obtained moreover lend unequivocal support to the usefulness of a relational framework integrating multiple levels of analysis along the lines suggested by Syed and Ozbilgin (in press) in future research relating to women entrepreneurship. 
Our excursion in the Lebanese context suggests that women entrepreneurs are facing a variety of obstacles, with the most important attributed to the nature of normative institutions, which have become broadly diffused to the extent of taking "a rule like status in social life" as suggested by Covaleski and Dirsmith (1988). The ascription of women to family and childcare responsibilities has created latent tensions and guilt feelings for all the women interviewed, given pressures for conformity with prevailing (un-codified) value standards. While the Lebanese women entrepreneurs did not succumb to these pressures, they nevertheless reported it as a serious uphill struggle in terms of reconciling work and family within largely internalized and taken for granted norms of behavior and appropriateness in their society.

Other normative constraints encountered included the permeation of entrepreneurship with traditional male stereotypes and societal attitudes not supportive of the work of women in general. Various macro level constraints were further identified including lack of government support, serious economic recession and stagnation as well as legal type constraints relating to extensive government procedures for example, suggesting the salience of structural barriers to female advancement in the Lebanese economy. Opportunities were in turn attributed mostly to micro level factors (e.g. motivation and opportunity identification). However, as reflected throughout the discussion, the disentanglement of those two levels of analysis (micro vs macro) was difficult to undertake in practice given their reciprocal influences and the embedded-ness of micro individual attitudes in broader organizational norms and societal traditions.

Our research makes two important contributions. The most important contribution lies in heeding recent calls for an integrative multi-level research design advocated by Bruin et al. (2007). Within the context of such an integrated framework, the study highlights through women entrepreneurs' interpretive accounts the complex interplay of individual-organizational - institutional variables in shaping their entrepreneurial identities, career choices and perceptions of opportunities and constraints. This integrated framework also helps accentuate and bring to light the embedded-ness of entrepreneurship and its context specificity, in the sense that our study clearly alerts to the strong salience of normative constraints encountered by Arab women generally, which has not been systematically studied and addressed in the mostly mainstream micro level studies relating to the topic.

While this paper has provided fruitful initial insights into factors affecting female entrepreneurship from a developing country perspective, the research admittedly has a number of limitations. The findings stem from a single-country investigation. This combined with the small sample size (10 participants) may imply that the results cannot be readily generalized, although they are likely to have wider relevance and applicability, particularly in developing countries. The evidence gathered is also based on self-reporting, given the qualitative interpretive approach adopted, hence raising the possibility of a potential social desirability response bias. Social desirability response bias has indeed been noted to be particularly salient in the context of developing and collectivist economies (Bernardi, 2006).

Going forward, it should be noted that most of the literature available on the topic of women entrepreneurship draws on experiences in the Anglo-Saxon countries, and hence the need for more research stemming from developing countries, which may indeed highlight the interplay of a different set or constellation of factors influencing
Constraints and opportunities facing women 
GM

24,4

248

female entrepreneurship. There is also a need to analyze women entrepreneurship through multiple lens and units of analysis as suggested in this paper, supplemented by research across groups of countries (e.g. transition economies). While the paper makes clear that an institutional focus is very much needed in developing countries, it should be supplemented by a dynamic view that recognizes the role of individual agency and learning capacity over time, given that, as suggested here, entrepreneurship is socially and historically embedded but also to some extent individually constructed and negotiated.

\section{References}

Achtenhagen, L. and Welter, F. (2003), "Female entrepreneurship in Germany: context development and its reflection in German media", in Butler, J. (Ed.), New Perspectives on Women Entrepreneurship, Information Age Publishing, Greenwich, CT, pp. 77-100.

Acs, Z., Arenius, P., Hay, M. and Minniti, M. (2005), 2004 Global Entrepreneurship Monitor Exclusive Report, London Business School, London and Babson College, Babson Park, MA.

Ahl, H. (2006), "Why research on women entrepreneurs needs new directions", Entrepreneurship Theory \& Practice, Vol. 30 No. 5, pp. 595-621.

Aidis, R., Welter, F., Smallbone, D. and Isakova, N. (2007), "Female entrepreneurship in transition economies: the case of Lithuania and Ukraine", Feminist Economics, Vol. 13 No. 2, pp. $157-83$.

Anna, A., Chandler, G., Jansen, E. and Mero, N. (2000), "Women business owners in traditional and non traditional industries", Journal of Business Venturing, Vol. 15 No. 3, pp. 279-303.

Arenius, P. and Minniti, M. (2005), "Perceptual variables and nascent entrepreneurship", Small Business Economics, Vol. 24, pp. 233-47.

Baker, T. and Nelson, R. (2005), "Creating something from nothing: resource construction through entrepreneurship bricolage”, Administrative Science Quarterly, Vol. 50, pp. 329-66.

Baughn, C., Chua, B.L. and Neupert, K. (2006), “The normative context for women's participation in entrepreneurship: a multi-country study", Entrepreneurship Theory \& Practice, Vol. 30 No. 5, pp. 687-708.

Bird, B. and Brush, C. (2002), "A gendered perspective on organisational creation", Entrepreneurship Theory and Practice, Vol. 26 No. 3, pp. 41-66.

Bernardi, R. (2006), “Associations between Hofstede's cultural constructs and social desirability response bias", Journal of Business Ethics, Vol. 65, pp. 43-53.

Boden, R.J. and Nucci, A. (2002), "On the survival prospects of men's and women's new business ventures”, Journal of Business Venturing, Vol. 15 No. 4, pp. 347-62.

Bruin, A., Brush, C. and Welter, F. (2007), "Advancing a framework for coherent research on women's entrepreneurship”, Entrepreneurship Theory \& Practice, Vol. 31 No. 3, pp. 323-39.

Carter, N. and Brush, C. (2005), "Gender", in Gartner, W., Shaver, K., Carter, N. and Reynolds, P. (Eds), Handbook of Entrepreneurial Dynamics: The Process of Business Creation, Sage, Thousand Oaks, CA, pp. 12-25.

Carter, N. and Kolvereid, I. (1997), "Women starting new businesses: the experience in norway and the US", paper presented at OECD Conference on Women Entrepreneurs in SMEs, Paris.

Carter, N., Anderson, S. and Shaw, E. (2001), Women's Business Ownership: A Review of the Academic, Popular and Internet Literature, report to the Small Business Service, Department of Trade and Industry, London. 
Carter, N.M. and Williams, M.L. (2003), "Comparing social feminism and liberal feminism: the case of new firm growth", in Butler, J.E. (Ed.), New Perspectives on Women Entrepreneurs, Information Age Publishing, Greenwich, CT, pp. 25-50.

Cosh, A. and Hughes, A. (2000), British Enterprise in Transition: Growth Innovation and Public Policy in the Small and Medium Sized Enterprise Sector 1994-1999, ESRC Centre for Business Research University of Cambridge, Cambridge.

Covaleski, M.A. and Dirsmith, M.W. (1988), "An institutional perspective on the rise, transformation and fall of a university budget category", Administrative Science Quarterly, Vol. 33, pp. 562-87.

Davidsson, P. and Wiklund, J. (2001), "Levels of analysis in entrepreneurship research: current research practice and suggestions for the future", Entrepreneurship Theory \& Practice, Vol. 25 No. 4, pp. 81-99.

DeTienne, D. and Chandler, G. (2007), "The role of gender in opportunity identification", Entrepreneurship Theory \& Practice, Vol. 31 No. 3, pp. 365-86.

Eckhardt, J. and Shane, S. (2003), "Opportunities and entrepreneurship”, Journal of Management, Vol. 29 No. 3, pp. 333-49.

Economic and Social Commission for Western Asia (2004), Where do Arab Women Stand in the Development Process: A Gender-Based Statistical Analysis, United Nations, New York, NY.

Eddleston, K. and Powell, G. (2008), "The role of gender identity in explaining sex differences in business owners career satisfier preferences", Journal of Business Venturing, Vol. 23, pp. 244-56.

Gartner, W. (2005), "Aspects of organizational emergence", in Bull, I., Thomas, H. and Willard, G. (Eds), Entrepreneurship: Perspectives on Theory Building, Pergamon, Oxford, pp. 67-86.

Gephart, R. (2004), "Qualitative research and the academy of management journal”, Academy of Management Journal, Vol. 47 No. 4, pp. 454-62.

Glaser, B. and Strauss, A. (1967), Discovery of Grounded Theory: Strategies for Qualitative Research, Aldine, Chicago, IL.

Greene, P.M., Hart, M., Gatewook, E., Brush, C. and Carter, N. (2003), Women Entrepreneurs: Moving Front and Center: An Overview of Research and Theory, White paper series, US Association for Small Business and Entrepreneurship, Boca Raton, FL.

Haddad, N. (1993), "Entrepreneurship in small industries in the Arab countries", Proceedings of the Expert Group Meeting on Creation of Indigenous Entrepreneurship, ESCWA, Damascus.

Hughes, K. (2003), “Pushed or pulled: women's entry into self-employment and small business ownership", Gender, Work and Organization, Vol. 10 No. 4, pp. 433-54.

Human Development Report (2008), Gender Related Development Index, United Nations Development Program, New York, NY.

Husseini, R. (1997), "Promoting women entrepreneurs in Lebanon: the experience of UNIFEM", Gender and Development, Vol. 5 No. 1, pp. 49-53.

IFF (2005), Corporate Governance in Lebanon - An Investor Perspective, Institute for International Finance, Task Force Report, IIF Equity Advisory Group, Washington, DC.

International Finance Corporation (2007), Gender Entrepreneurship Markets (GEM) GEM Country Brief-Lebanon 2007, International Finance Corporation, World Bank Group, Washington, DC.

\section{Constraints and opportunities facing women}

249 
GM

24,4

250
International Finance Corporation \& Center of Arab Women for Training and Research (2007), Women Entrepreneurs in the Middle East and North Africa: Characteristics, Contributions and Challenges, International Finance Corporation, World Bank Group, Washington, DC.

Jamali, D., Safieddine, A. and Daouk, A. (2006), "The glass ceiling: some positive trends from the lebanese banking sector", Women in Management Review, Vol. 21, pp. 625-42.

Jamali, D., Sidani, Y. and Safieddine, A. (2005), "Constraints facing working women in Lebanon: an insider View”, Women in Management Review, Vol. 20 No. 8, pp. 581-94.

Langowitz, N. and Minniti, M. (2007), "The entrepreneurial propensity of women”, Entrepreneurship Theory \& Practice, Vol. 31 No. 3, pp. 341-64.

McManus, P.A. (2001), "Women's participation in self-employment in western industrialized nations", International Journal of Sociology, Vol. 31 No. 2, pp. 70-97.

Marlow, S. and Patton, D. (2005), "All credit to men? Entrepreneurship, finance, and gender", Entrepreneurship Theory \& Practice, Vol. 29 No. 6, pp. 717-35.

Minniti, M., Arenius, P. and langowitz, N. (2005), 2004 Global Entrepreneurship Monitor Special Topic Report: Women and Entrepreneurship, Center for Women's Leadership at Babson College, Babson Park, MA.

Nooderhaven, N., Thurik, R., Wonnekers, S. and van Stel, A. (2004), "The role of dissatisfaction and per capita income in explaining self-employment across 15 European countries", Entrepreneurship Theory \& Practice, Vol. 28 No. 5, pp. 447-66.

North, D. (1990), Institutions, Institutional Change and Economic Performance, Cambridge University Press, Cambridge.

Patton, M. (2002), Qualitative Research \& Evaluation Methods, 3rd ed., Sage, London.

Pistrui, D., Fahed-Sreih, J., Huang, W. and Welsch, H. (2008), "Entrepreneurial led family business development in post-war Lebanon", USASBE 2008 Proceedings, pp. 847-62.

Reynolds, P., Bygrave, W. and Autio, E. (2003), “GEM 2003 global report” (draft released January 8, 2004), E.M. Kauffman Foundation, Kansas City, MO available at: www.kauffman,org/pdf/ gem_2003_global_report.pdf (accessed January 22, 2006).

Samaha, N. (2007), “Arab women entrepreneurs outpace Westerners by some measures”, Daily Star, June 5.

Scott, W.R. (1995), Institutions and Organizations, Sage, Thousand Oaks, CA.

Sha'rani, A. (2004), "The Lebanese women: reality and aspirations", available at: www.nclw. org.lb/lebanesemid.cfm, Internet (accessed May 15, 2006).

Shaw, E., Carter, S. and Brierton, J. (2001), Unequal Entrepreneurs: Why Female Enterprise is an Uphill Business', The Industrial Society, London.

Sidani, Y. (2002), "Management in Lebanon", in Warner, M. (Ed.), International Encyclopedia of Business and Management, 2nd ed., Thomson Learning, London, pp. 3797-802.

Syed, J. and Ozbilgin, M. (in press), "A relational framework for international transfer of diversity management practices", International Journal of Human Resource Management (in press).

Verheul, I., Van Stel, A. and Thurik, R. (2006), "Explaining female and male entrepreneurship at the country level”, Entrepreneurship \& Regional Development, Vol. 18, pp. 151-83.

Welter, F., Smallbone, D., Aculai, E., Isakova, N. and Schakirova, N. (2003), "Female entrepreneurship in post-soviet countries, in", in Butler, J. (Ed.), New Perspectives on Women Entrepreneurship, Information Age Publishing, Greenwich, CT, pp. 243-69. 
World Bank (2005), "The status and progress of women in the Middle East and North Africa", World Bank Middle East and North Africa Socio-Economic Development Group, Washington, DC.

Constraints and opportunities facing women

\section{Further reading}

Cockburn, C. (1991), In The Way of Women, Methuen, London.

Isabella, L. (1990), "Evolving interpretations as a change unfolds: how managers construe key organizational events", Academy of Management Journal, Vol. 33 No. 1, pp. 7-41.

\section{Corresponding author}

Dima Jamali can be contacted at: djoo@aub.edu.lb 